\title{
Lead Speciation in the Dusts Emitted from Non-Ferrous Metallurgy Processes
}

\author{
Marianna Czaplicka $\cdot$ Lucja Buzek
}

Received: 24 May 2010 / Accepted: 8 September 2010/Published online: 23 September 2010

(C) The Author(s) 2010. This article is published with open access at Springerlink.com

\begin{abstract}
The paper presents results for the speciation analysis of lead in dusts derived from dedusting of technological gasses from metallurgical processes of non-ferrous metals with different elementary content, made in accordance with two equal sequential extractions. Analytical procedure A provided possibilities for determination of fraction of $\mathrm{Pb}^{2+}$, metallic lead and fraction containing mainly lead sulfides. The second procedure (procedure B) was sequential extraction in accordance with Tessier. The results obtained in accordance with procedure $\mathrm{A}$ indicate that, regardless of the dust origin, the dominant group of $\mathrm{Pb}$ compounds is composed of lead salts which are soluble under alkaline conditions or lead compounds that form plumbites in the reaction with $\mathrm{NaOH}$.
\end{abstract}

Keywords Lead $\cdot$ Metallurgy $\cdot$ Dusts $\cdot$ Speciation

M. Czaplicka $(\bowtie) \cdot$ Ł. Buzek

Institute of Non-Ferrous Metals,

Sowińskiego Str. 5,

Gliwice 44-100, Poland

e-mail: mariannac@imn.gliwice.pl

M. Czaplicka

Department of Chemistry, Silesian Technical University,

M. Strzody Str. 3,

Gliwice 44-100, Poland

\section{Introduction}

Lead metallurgy is one of the most significant sources of $\mathrm{Pb}$ emission to the environment. Numerous studies indicate the direct impact of emission of metals, which accompany lead metallurgical processes, on the quality of air. It is well-known fact that the emitted from metallurgical processes dusts which contain $\mathrm{Pb}$ are mainly airborne and represent the longest-term pollution effect of metallurgy, especially in agriculture. As a result of deposition, $\mathrm{Pb}$ from air is introduced into the water-soil environment, where it undergoes biochemical transformations. Previous studies showed that fly ash from secondary $\mathrm{Pb}$ smelters can be highly reactive in aqueous solutions (Ettler et al. 2005a, b). The interest in speciation analysis has increased considerably in the recent years, especially in relation to the assessment of influence of metallurgical installation on the watersoil environment. The knowledge of content of bioassimilable metal forms in soils is an important factor in evaluation of exposure of ecosystems to anthropogenic pollutants. A combination of sequential extraction results with the knowledge of other chemical properties of soil is very useful in determination of potential "mobile fraction" of metals in soil. The degree of metal ion binding with stationary phase depends on the type of ion, $\mathrm{pH}$, temperature, redox potential and, in the case of soils, also on the composition of organic material and activity of 
microorganisms. The type of organic-mineral binding, the degree of saturation with metallic ion, adsorption of the complex on mineral particle of soil, as well as biodegradation of organic component of the complex determine the mobility of metallic ions in soil. Examinations of soils around the Pribram lead metallurgical plant, located in the Czech Republic, showed that the content of $\mathrm{Pb}$ in the soils ranges from 1.2 to $35.3 \mathrm{~g} / \mathrm{kg}$, with $\mathrm{Pb}$ deposition from 5 to $89 \mathrm{mg} \mathrm{m}^{-2}$ per year (Mihaljevič et al. 2006).

Speciation analysis of lead in various matrices was a subject of many publications (Ettler et al. 2005c; Mihaljevič et al. 2006; Sammut et al. 2010; Sobanska et al. 1999; Batonneau et al. 2004; Clevenger et al. 1991; Kozelka et al. 1997; Okada and Matsuto 2009; Kabala and Singh 2001; Morin et al. 1999; Chiaradia et al. 1997; Sammut et al. 2008). The majority of the proposed analytical procedures is based on the methodology developed by Tessier et al. (1979) or its modification (Grimalt 1989), involving sequential extraction of five fractions, i.e., (1) exchangeablesalt displaceable, (2) acid extractable-bound to carbonates and, specifically, sorbed, (3) reduciblebound to Fe and Mn oxides, (4) oxidisable — strongly complexed with organic matter and bound to sulfides, (5) residual-silicates. In most cases, the highest $\mathrm{Pb}$ content was found in the exchangeable fraction which contains metals easily distributed in the environment (Ettler et al. 2005c). The results of the studies by Sammut et al. (2010) indicate that the dominant $\mathrm{Pb}$ compound occurring in the dusts emitted by a sintering plant is $\mathrm{PbCO}_{3} \cdot 2 \mathrm{H}_{2} \mathrm{O}$, formed in a reaction of $\mathrm{Pb}$ with $\mathrm{CO}_{2}$ and present in sintering gasses at considerable concentration. Somewhat different profile of lead compounds is observed for dusts coming from lead metallurgy. The off-gas from lead smelters is mainly $\mathrm{SO}_{2}$, which explains the association of $\mathrm{Pb}$ with sulfates, sulfides or oxides (Sobanska et al. 1999; Batonneau et al. 2004; Clevenger et al. 1991). Okada and Matsuto (2009) applied sequential extraction of lead compounds comprising: separation of mainly $\mathrm{PbCl}_{2}$ and $\mathrm{Pb}\left(\mathrm{NO}_{3}\right)_{2}$ by extraction with water, then separation of $\mathrm{PbSO}_{4}, \mathrm{PbCl}_{2}$ and $\mathrm{Pb}\left(\mathrm{NO}_{3}\right)_{2}$ with a use of $\mathrm{Na}_{2} \mathrm{~S}_{2} \mathrm{O}_{3} . \mathrm{PbO}, \mathrm{PbSO}_{4}, \mathrm{PbCl}_{2}$, and $\mathrm{Pb}\left(\mathrm{NO}_{3}\right)_{2}$ were extracted with $\mathrm{CH}_{3} \mathrm{COONH}_{4}$ solution, while $\mathrm{Pb}^{0}$, $\mathrm{PbCl}_{2}$, and $\mathrm{Pb}\left(\mathrm{NO}_{3}\right)_{2}$ with $\mathrm{AgNO}_{3}$ solution. For the separation of the mixture which contains $\mathrm{PbCl}_{2}, \mathrm{~Pb}$ $\left(\mathrm{NO}_{3}\right)_{2}, \mathrm{PbO}, \mathrm{PbSO}_{4}, \mathrm{PbO} \cdot \mathrm{H}_{2} \mathrm{O}$, and $\mathrm{PbCO}_{3}$ a solution of $\mathrm{NaOH}$ was applied.

The aim of the studies was to compare two sequential $\mathrm{Pb}$ extraction procedures for the dusts emitted during lead metallurgical processes. The first one (procedure A) provided possibilities to determine participation of lead compounds in the dusts from the technological point of view of their exploitation, the second (procedure B) gave possibility to determine mobility of the dusts in a case of introducing them into the environment. For each procedure, the sum of lead in the extraction steps was compared with the total $\mathrm{Pb}$ concentration in the dusts.

\section{Material and Methods}

Speciation analysis of lead was carried out with averaged samples of dust derived from dedusting of technological gasses from non-ferrous metals metallurgical processes, such as: dusts from an electric furnace, Dörschel furnace, a converter furnace, an anodic furnace and recycled dusts. Samples were taken from the streams of technological gasses by external filtration method. Elemental composition of dusts is presented in Table 1 .

Table 1 Elementary composition of dusts

\begin{tabular}{lcccccccccccc}
\hline Sample & $\mathrm{As} \%$ & $\mathrm{~Pb} \%$ & $\mathrm{Cu} \%$ & $\mathrm{Zn} \%$ & $\mathrm{~S} \%$ & $\mathrm{Fe} \%$ & $\mathrm{CaO} \%$ & $\mathrm{SiO}_{2} \%$ & $\mathrm{Na} \%$ & $\mathrm{~K} \%$ & $\mathrm{Ag} \mathrm{ppm}$ & $\mathrm{Cl} \%$ \\
\hline Electric furnace & 0.37 & 46.00 & 0.76 & 24.8 & 1.47 & 0.18 & 0.88 & 1.25 & 0.80 & 4.06 & 53 \\
Dörschla furnace & 5.98 & 41.20 & 0.42 & 9.00 & 6.11 & 0.46 & 0.31 & 0.43 & 2.68 & 6.08 & 83 & 9.74 \\
Converter furnace & 0.91 & 45.30 & 0.83 & 11.2 & 11.7 & 0.11 & $<0.02$ & $<0.01$ & 0.09 & 0.42 & 220 & 0.09 \\
Anodic furnace & 24.5 & 14.65 & 17.48 & 0.44 & 5.80 & 0.34 & 0.1 & 0.1 & no & 1.6 & no & 0.2 \\
Recycle dusts & 6.20 & 44.00 & 0.38 & 7.82 & 6.05 & 0.50 & 0.12 & $<0.01$ & 2.54 & 6.61 & 83 & 10.0 \\
\hline
\end{tabular}

no no determinated 
Table 2 Method accuracy for $n=6$ repetitions

\begin{tabular}{lcccc}
\hline Parameter & $\mathrm{Pb}^{2+} \%$ & $\mathrm{~Pb}^{0} \%$ & $\mathrm{PbS} \%$ & Total Pb\% \\
\hline Average, \% & 13.47 & 0.22 & 0.21 & 94.86 \\
Standard deviation, s.\% & 0.40 & 0.05 & 0.05 & 2.67 \\
Relative standard deviation, RSD \% & 0.03 & 0.23 & 0.24 & 0.03 \\
Coefficient of variability, \% & 3.0 & 22 & 24 & 3.0 \\
\hline
\end{tabular}

with $50 \mathrm{ml}$ of $2 \% \mathrm{NaOH}$ solution during $1 \mathrm{~h}$;

The elemental composition of examined dusts was determined in accordance to the following methods:

- total $\mathrm{Pb}$ content in examined dusts was determined using complexometric titration with EDTA solution after its separation in the form of the lead (II) sulfate;

- content of sulfur was determined by gravimetric method after its precipitation in the form of barium sulfate;

- chlorides were determined using potential titration method;

- content of the silicon dioxide was determined by gravimetric method after its precipitation in the form of silicic acid.

Contents of $\mathrm{As}, \mathrm{Cu}, \mathrm{Zn}, \mathrm{Fe}, \mathrm{CaO}, \mathrm{Na}, \mathrm{K}, \mathrm{Ag}$ were determined by atomic absorption spectrophotometry (AAS) technique, after diluting the samples in acids, and then by measurement of the atomic absorption obtained analytes at the wavelength characteristic for every elements.

Concentration of lead was determined by means of FAAS technique, with a use of SOLAAR S4 spectrometer. Statistical evaluation of the procedure is presented in Table 2 .

\subsection{Extraction for Lead Forms-Procedure A}

Samples with the mass of $0.1 \mathrm{~g}$ were studied. The following leaching parameters were applied:

Fraction I lead fraction containing $\mathrm{Pb}^{2+}$ compounds except for sulfides; extraction
Fraction II metallic lead fraction $\left(\mathrm{Pb}^{0}\right)$; extraction with $25 \mathrm{ml}$ of $5 \% \mathrm{AgNO}_{3}$ solution during $1.5 \mathrm{~h}$;

Fraction III fraction containing lead sulfides; extraction with $100 \mathrm{ml}$ of alcohol with addition of bromine during $2 \mathrm{~h}$;

residue.

During lead extraction, the content of the beaker was stirred with a magnetic stirrer at constant speed of $900 \mathrm{rpm}$. When mixing was finished, the solution was filtered through a single glass fiber filter using a vacuum pump. After each filtration, the beaker in which extraction was carried out and the deposit on the filter were washed with a few milliliter of leaching solution. As a result, three solutions and a digested sludge were obtained. Solution and deposit were produced from every leaching operation, and the deposit was leached again. $\mathrm{Pb}$ content was determined in solutions from every stage of leaching and in the last deposit (remains after leaching) by FAAS technique.

Quantitative analysis of particular fractions was performed as follows:

1. $2 \% \mathrm{NaOH}$ solution, which contained $\mathrm{Pb}^{+2}$, was acidified with acetic acid, lead was precipitated in the form of lead chromate $\left(\mathrm{PbCrO}_{4}\right)$, which, after filtration, was dissolved in hydrochloric acid. The solution was appropriately diluted and analyzed;

2. $5 \%$ solution of silver nitrate, which contained metallic lead, was acidified with nitric acid, suitably diluted, and analyzed by AAS method;
Table $3 \mathrm{~Pb}$ forms content in dusts - procedure A
${ }^{\mathrm{a}}$ Without $\mathrm{PbS}$

\begin{tabular}{lccccc}
\hline Sample & $\mathrm{Pb}^{+2} \%^{\mathrm{a}}$ & $\mathrm{Pb}^{0} \%$ & $\mathrm{PbS} \%$ & $\mathrm{~Pb}$ residue\% & Total\% \\
\hline Electric furnace & 31.10 & 4.61 & 4.55 & 3.77 & 44.03 \\
Dörschla furnace & 31.13 & 4.74 & 4.24 & 0.50 & 40.61 \\
Converter furnace & 35.20 & 0.03 & 4.78 & 3.02 & 43.02 \\
Anodic furnace & 13.26 & 0.20 & 0.31 & 0.20 & 13.97 \\
Recycle dusts & 24.05 & 6.38 & 7.94 & 0.76 & 39.13
\end{tabular}


Table 4 Sequential chemical extraction procedure

\begin{tabular}{lll}
\hline Fractions & Speciation & Procedure \\
\hline (1) & Exchangeable & $1 \mathrm{M} \mathrm{CH}_{3} \mathrm{COONH}_{4} ; \mathrm{pH}=7$; (shaking for $1 \mathrm{~h}$ at room temperature) \\
$(2)$ & Carbonates (acid extractable) & $1 \mathrm{M} \mathrm{CH}_{3} \mathrm{COONH}_{4}$ acidified with $\mathrm{CH}_{3} \mathrm{COOH}$ to $\mathrm{pH} 5$ (shaking for $5 \mathrm{~h}$ at room temperature) \\
$(3)$ & Fe and $\mathrm{Mn}$ oxides (reducible) & $0,04 \mathrm{M} \mathrm{NH}_{2} \mathrm{OH} \cdot \mathrm{HCl}$ in $25 \% \mathrm{CH}_{3} \mathrm{COOH}$ (shaking for $5 \mathrm{~h}$ at $\left.95^{\circ} \mathrm{C}\right)$ \\
$(4)$ & Residual & $10 \mathrm{M} \mathrm{HNO}_{3}+\mathrm{H}_{2} \mathrm{O}_{2}$ (shaking for $1 \mathrm{~h}$ ) $+\mathrm{H}_{2} \mathrm{O}$ (shaking for $0,5 \mathrm{~h}$ at boiling point) \\
\hline
\end{tabular}

3. alcoholic solution, which contained lead in the form of sulfides, was subjected to slow evaporation of alcohol, decomposition of bromides and removal of bromine by heating it with nitric acid and a small amount (one drop) of sulfuric acid;

4. the digested sludge was subjected to hot leaching with hydrochloric and nitric acids, suspension was filtered off and the content of lead in the filtrate after dilution was determined.

The obtained results are collected in Table 3 .

\subsection{Extraction for Lead Forms-Procedure B}

Simultaneously, the same samples were subjected to modified sequential extraction in accordance with the scheme proposed by Tessier et al. Table 4 gives details of the different steps and experimental conditions. In the adopted analytical procedure, it was decided to resign from separation of the fraction, which contained organic species of $\mathrm{Pb}$ and $\mathrm{PbS}$. Because of technological conditions, determination of organic lead compounds in the dusts from pyrometallurgical processes was consid- ered unjustified, whereas lead sulfides were separated together with the residue. The content of lead compounds in the separated fractions is given in Table 5.

For each procedure, the sum of lead in the extraction steps is compared with the total concentration of $\mathrm{Pb}$ in the dusts.

\section{Results and Discussion}

The works of Sobanska et al. (1999) and Ohmsen (2001) focused on primary $\mathrm{Pb}$ smelter dusts and emissions, and showed that the chemistry and mineralogy of emissions can be extremely complex, depending on (1) temperature of the flue gas cleaning process, (2) nature of the cooling media (water and air) during dust collection, and (3) chemistry of the blast-furnace charge. Data presented in Table 1 indicate considerable diversification of elemental composition of dusts, depending on the technological stage. The lead content ranges from $14.7 \%$, in the case of the dusts from the anodic furnace, to $46 \%$ (dusts from the electric furnace). Except for the

Table 5 Distribution of lead in fractions according Tessier procedure (B)

\begin{tabular}{|c|c|c|c|c|c|}
\hline \multirow[t]{2}{*}{ Sample } & \multicolumn{5}{|l|}{$\mathrm{Pb}$ content,$\%$} \\
\hline & $\begin{array}{l}\text { Fraction }(1)- \\
\text { exchangeable containing } \\
\text { salt displaceable }\end{array}$ & $\begin{array}{l}\text { Fraction (2)-acid } \\
\text { extractable-bound to } \\
\text { carbonates and specifically } \\
\text { sorbet lead compounds }\end{array}$ & $\begin{array}{l}\text { Fraction }(3)- \\
\text { reducible- - bound to } \\
\text { Fe and Mn oxides }\end{array}$ & $\begin{array}{l}\text { Fraction (4) - residual } \\
\text { containing organic species } \\
\text { of } \mathrm{Pb}, \mathrm{PbS} \text {, and residue }\end{array}$ & Total $\mathrm{Pb}$ \\
\hline $\begin{array}{l}\text { Electric } \\
\text { furnace }\end{array}$ & 23.3 & 17.4 & 3.4 & 0.4 & 44.5 \\
\hline $\begin{array}{r}\text { Dörschla } \\
\text { furnace }\end{array}$ & 11.4 & 12.8 & 2.1 & 14.5 & 40.8 \\
\hline $\begin{array}{c}\text { Converter } \\
\text { furnace }\end{array}$ & 15.7 & 24.2 & 4.2 & 2.3 & 46.4 \\
\hline Recycle dusts & 7.8 & 5.3 & 5.8 & 22.1 & 41.0 \\
\hline
\end{tabular}


anodic furnace dusts, lead is the main element in all the emitted dusts. In dusts from the anodic furnace, the main element was As.

Procedure A, representing chemical fractionation of lead, provided possibilities for the recovery of lead species from dusts at the level of 95-98.6\%. Evaluation of precision of the method revealed that the proposed analytical procedure is characterized by uncertainty of recovery equal to $3.0 \%$ (Table 2). However, it should be noted that, in the case of $\mathrm{Pb}$ determinations for a fraction with low lead content, the uncertainty is estimated to be between $22 \%$ and $24 \%$. Standard deviation for lead determination in the separated fractions falls within the range between $0.05 \%$ and $2.67 \%$ and meets the requirements established for instrumental procedures (Okada and Matsuto 2009).

Speciation analysis according to procedure A showed that, among all the examined samples of dusts, the dominant fraction is fraction I, which contains lead compounds soluble under alkaline conditions, $\mathrm{Pb}^{+2}$ compounds or lead compounds undergoing a reaction during extraction with $\mathrm{NaOH}$ (Table 3). According to the data presented by Okada and Matsuto (2009), this fraction may contain such compounds as: $\mathrm{PbCl}_{2}, \mathrm{~Pb}\left(\mathrm{NO}_{3}\right)_{2}, \mathrm{PbSO}_{4}, \mathrm{PbO}$, and $\mathrm{PbCO}_{3}$. The percentage of this fraction in the total lead content in the emitted dusts ranges from $71 \%$ to $82 \%$, depending on the technological stage of the lead metallurgy process. Taking into account the results

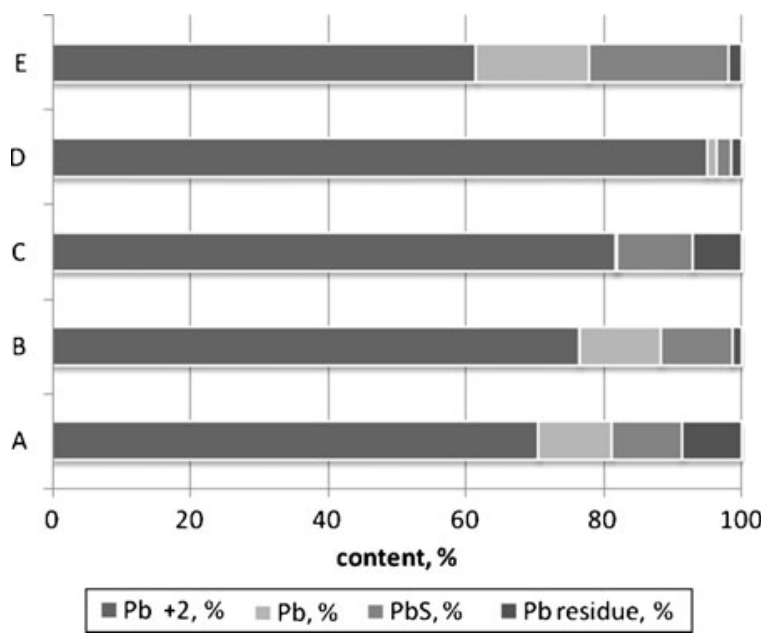

Fig. 1 Distribution of $\mathrm{Pb}$ forms in total $\mathrm{Pb}$ for procedure (A);A electric furnace, $B$ Dörschel furnace, $C$ converter furnace, $D$ anodic furnace, $E$ recycle dusts

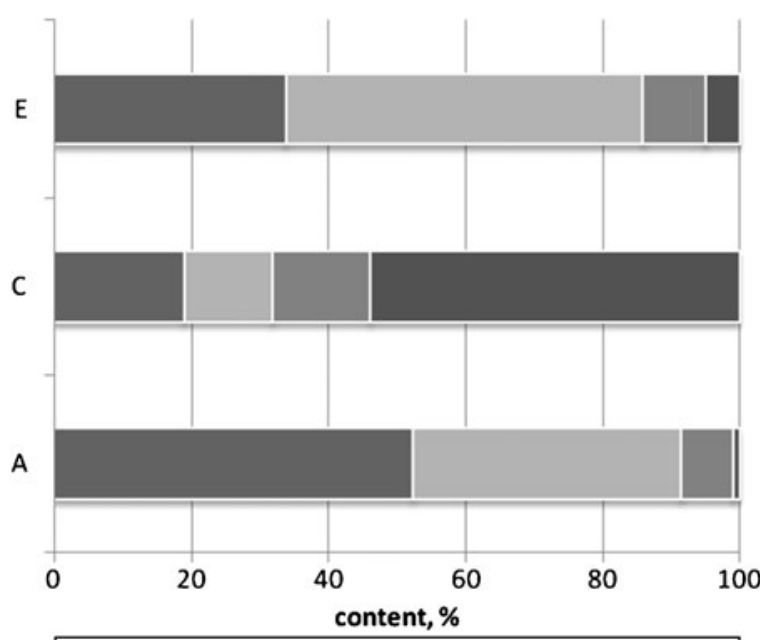

- fraction I | fraction II | fraction III $\mid$ fraction IV $+V$

Fig. 2 Distribution of $\mathrm{Pb}$ forms in total $\mathrm{Pb}$ for procedure (B); $A$ electric furnace, $C$ converter furnace, $E$ recycle dusts

presented by Sobanska et al. (1999) and the mechanisms of elementary reactions taking place during metallurgical processes it can be supposed that, under the conditions of non-ferrous metals production, the content of the fraction I will be diversified. Because of high $\mathrm{SO}_{2}$ concentration in gasses and presence of the alkalis in the materials of the process, this fraction in dusts from electric furnaces will contain mainly $\mathrm{PbSO}_{4}$ and plumbites of potassium and sodium. The similar situation is observed with the dusts from converters, where $\mathrm{PbSO}_{4}$ will also be the dominating $\mathrm{Pb}$ compound. Composition of the gasses from the Dörschel and anodic furnaces is characterized by high $\mathrm{CO}_{2}$ content, which influences the high content of $\mathrm{PbCO}_{3}$ in fraction I of these dusts. Additionally, in dusts from Dörschel furnaces, this fraction contains $\mathrm{PbCl}_{2}$ and plumbites. Moreover, the main $\mathrm{Pb}$ compounds in the recycled dusts are plumbites. It should also be noted that in the proposed sequential extraction, the majority of lead salts will undergo a

Table $6 \mathrm{~Pb}$ mobile factor $(\%)$ in dust

\begin{tabular}{ll}
\hline Sample & Mobile factor \% \\
\hline Electric furnace & 91 \\
Dörschla furnace & 59 \\
Converter furnace & 86 \\
Recycle dusts & 32 \\
\hline
\end{tabular}


reaction with $\mathrm{NaOH}$, resulting in formation of sodium plumbite, soluble under alkaline conditions, according to the reaction:

$\mathrm{PbX}+\mathrm{NaOH} \rightarrow \mathrm{Na}_{2} \mathrm{PbO}_{2}+\mathrm{NaX}+2 \mathrm{H}_{2}$

where $\mathrm{X}$ - anion, e.g., $\mathrm{SO}_{4}{ }^{-}$

The fraction of metallic lead in the total lead content in the examined dusts was within the range between $0.1 \%$ and $16.3 \%$. The highest $\mathrm{Pb}^{0}$ percentage was characteristic for the recycled dusts, whereas it was the lowest for dusts from the converter and anodic furnaces. Lead in the form of PbS constituted from $2.2 \%$ (recycled dusts) to 20\% (anodic furnace) of the total lead content. Contents of the particular $\mathrm{Pb}$ species in dusts are presented in Fig. 1.

The Procedure B established by Tessier et al. (1979), based on determination of mobility of individual forms of an element in the environment, is commonly applied to evaluate the behavior of metals in the soil environment. Speciation analysis of the lead in the dusts from lead metallurgy, carried out in accordance with the modified Tessier scheme (procedure B), also demonstrated considerable diversification of the percentage of $\mathrm{Pb}$ species, depending on the dust origin (Table 5). $\mathrm{Pb}$ in the fraction (1) exchangeable containing displaceable salts constitutes from $7.8 \%$ to $23.3 \%$ of the dust. This fraction contains, among other compounds, $\mathrm{PbSO}_{4}, \mathrm{PbO}$, and $\mathrm{PbO}$, which are easily soluble in $1 \mathrm{M} \mathrm{CH}_{3} \mathrm{COONH}_{4}$. The highest content of exchangeable $\mathrm{Pb}$ was characteristic for the electric furnace dust, while it was the lowest for the recycled dust. The $\mathrm{Pb}$ content in the fraction (2), involving acid extractable-bound to carbonates and, specifically, sorbed lead compounds, comprises from 5.3\% (recycled dust) to $24.3 \%$ (converter furnace dust) of the dust. This fraction contains mainly lead carbonate and insoluble salts. From $2.1 \%$ to $5.8 \%$ of lead is present in the fraction (3) reducible - bound to Fe and Mn oxides. The lead in the residue constitutes from $0.4 \%$ to $22 \%$ of the dust. The remaining part consists of: $\mathrm{Pb}$ which is bound to the phases easily soluble under oxidizing conditions, such as sulfides; and metal present in crystalline structure of primary and secondary minerals, soluble under strongly acidic condition. The percentages of the particular lead species in reference to the total content of this element are presented in Fig. 2. The mean recovery of lead from dusts in that analytical procedure was $97.6 \%$.

Oxides, sulfates, and carbonate of lead for the procedure $\mathrm{B}$ are predominantly dissolved during the exchangeable and mildly acidic steps of the sequential extraction procedure, while lead sulfides and mineral silicate predominantly dissolved in the oxidizable and residual steps. Differences of the $\mathrm{Pb}$ content in the $\mathrm{Pb}^{2+}$ fraction and sums of the $\mathrm{Pb}$ content in fractions (1) and (2) procedure $\mathrm{B}$ most probably result from the partial extraction by $\mathrm{CH}_{3} \mathrm{COONH}_{4}$ of such lead compounds as: $\mathrm{PbS}, \mathrm{PbCO}_{3}$, and $\mathrm{Pb}$ (Okada and Matsuto 2009).

Exchangeable and acid extractable fractions are considered to be easily available (Morin et al. 1999). The mobility factor, determined according to Kabala and Singh (2001), has values ranging from $32 \%$ to $93 \%$, depending on the dust origin (Table 6). The obtained results indicate that dusts from the electric and converter furnaces contain the highest fraction of lead compounds which readily migrate in the environment.

The results obtained in accordance with procedure A indicate that, regardless of the dust origin, the dominant group of $\mathrm{Pb}$ compounds is composed of lead salts which are soluble under alkaline conditions or lead compounds that form plumbites in the reaction with $\mathrm{NaOH}$.

Determination of $\mathrm{Pb}$ content which is soluble in alkaline environment is important information for further use of the dusts as recyclable materials. The big portion of this fraction can be used as a raw material in pyro- and hydrometallurgical technologies of lead recycling. On the other hand, application of the modified Terrsier extraction shows high mobility of the lead from the dusts in water-soil environment, especially in the case of the dusts from electric and converter furnaces which amounts to $91 \%$ and $86 \%$, respectively. Such a high mobility factor indicates a big hazard resulting from the $\mathrm{Pb}$ proliferation in the environment.

Open Access This article is distributed under the terms of the Creative Commons Attribution Noncommercial License which permits any noncommercial use, distribution, and reproduction in any medium, provided the original author(s) and source are credited. 


\section{References}

Batonneau, Y., De Bremard, C., Gengembre, L., Laureyns, J., Le Maguer, A., Le Maguer, D., et al. (2004). Speciation of PM10 sources of airborne nonferrous metals within the $3-\mathrm{km}$ zone of lead/zinc smelters. Environmental Science \& Technology, 38, 5281.

Chiaradia, M., Gulson, B. L., James, M., Jameson, C. W., \& Johnson, D. (1997). Identification of secondary lead sources in the air of an urban environment. Atmospheric Environment, 31, 3511.

Clevenger, T. E., Salwan, C., \& Koirtyohann, S. R. (1991). Lead speciation of particles on air filters collected in the vicinity of a lead smelter. Environmental Science \& Technology, 25, 1128.

Ettler, V., Johan, Z., Baronnet, A., Jankovsky, F., Gilles, C., Mihaljevič, M., et al. (2005a). Mineralogy of air pollutioncontrol residues from a secondary lead smelter: environmental implications. Environmental Science \& Technology, 39, 9309.

Ettler, V., Mihaljevič, M., Šebek, O., \& Strnad, L. (2005b). Leaching of APC residues from secondary $\mathrm{Pb}$ metallurgy using single extraction tests: the geochemical and the mineralogical approach. Journal of Hazardous Materials, 121, 149.

Ettler, V., Vaněk, A., Mihaljevič, M., \& Bezdička, P. (2005c). Contrasting lead speciation in forest and tilled soils heavily polluted by lead metallurgy. Chemosphere, 58, 1449.

Grimalt, J. O. (1989). Sampling, sample handling and operational methods for the analysis of trace pollutants in the marine environment. [w]: Albaiges, J. (ed.), Mar. Pollut., Hemisphere, New York, p. 258.

Kabala, C., \& Singh, B. R. (2001). Fractionation and mobility of copper, lead and zinc in soil profiles in the vicinity of a copper smelter. Journal of Environmental Quality, 30, 485.

Kozelka, P. B., Sanudo-Wilhelmy, S., Flegal, A. R., \& Bruland, K. W. (1997). Physico-chemical speciation of lead in South San Francisco Bay. Estuarine, Coastal and Shelf Science, 44, 649.

Mihaljevič, M., Zuna, M., Ettler, V., Šebek, O., Strnad, L., \& Goliáš, V. (2006). Lead fluxes, isotopic and concentration profiles in a peat deposit near a lead smelter (Př́bram, Czech Republic). The Science of the Total Environment, $372,334$.

Morin, G., Ostergren, J. D., Juillot, F., Ildefonse, P., Calas, G., \& Brown, G. E. (1999). XAFS determination of the chemical forms of lead in smelter-contaminated soils and mine tailings; importance of adsorption processes. American Mineralogist, 84, 4204.

Okada, T., \& Matsuto, T. (2009). Determination of lead speciation In meting furnace fly ash by sequential chemical extraction. Chemosphere, 75, 272.

Ohmsen, G. S. (2001). Characterization of fugitive material within a primary lead smelter. Journal of the Air \& Waste Management Association, 51, 1443.

Sammut, M. L., Rose, J., Masion, A., Fiani, E., Depoux, M., Ziebel, A., et al. (2008). Determination of zinc speciation in basic oxygen furnace flying dust by chemical extraction and X-ray spectroscopy. Chemosphere, 70, 1945.

Sammut, M. L., Noack, Y., Rose, J., Hazemann, J. L., Proux, O., Depoux, M., et al. (2010). Speciation of $\mathrm{Cd}$ and $\mathrm{Pb}$ in dust emitted from sinter plant. Chemosphere, 78, 445.

Sobanska, S., Ricq, N., Laboudigue, A., Guillermo, R., Bremard, C., Laureyns, J., et al. (1999). Microchemical investigations of dust emitted by a lead smelter. Environmental Science \& Technology, 33, 1334-1339.

Tessier, A., Campbell, P. G. C., \& Bisson, M. (1979). Sequential extraction procedure for the speciation of particulate trace metals. Analytical Chemistry, 51, 844. 